\title{
Chemistry and Age of Groundevater in the Piceance Structural Basin, Rio Blanco County, Colorado, 2010-12
}

Fourteen monitoring wells were sampled by the U.S. Geological Survey, in cooperation with the Bureau of Land Management, to better understand the chemistry and age of groundwater in the Piceance structural basin in Rio Blanco County, Colorado (fig. 1), and how they may relate to the development of underlying naturalgas reservoirs (McMahon and others, 2013). Natural gas extraction in the area has been ongoing since at least the 1950s, and the area contains about 960 producing, shut-in, and abandoned natural-gas wells.

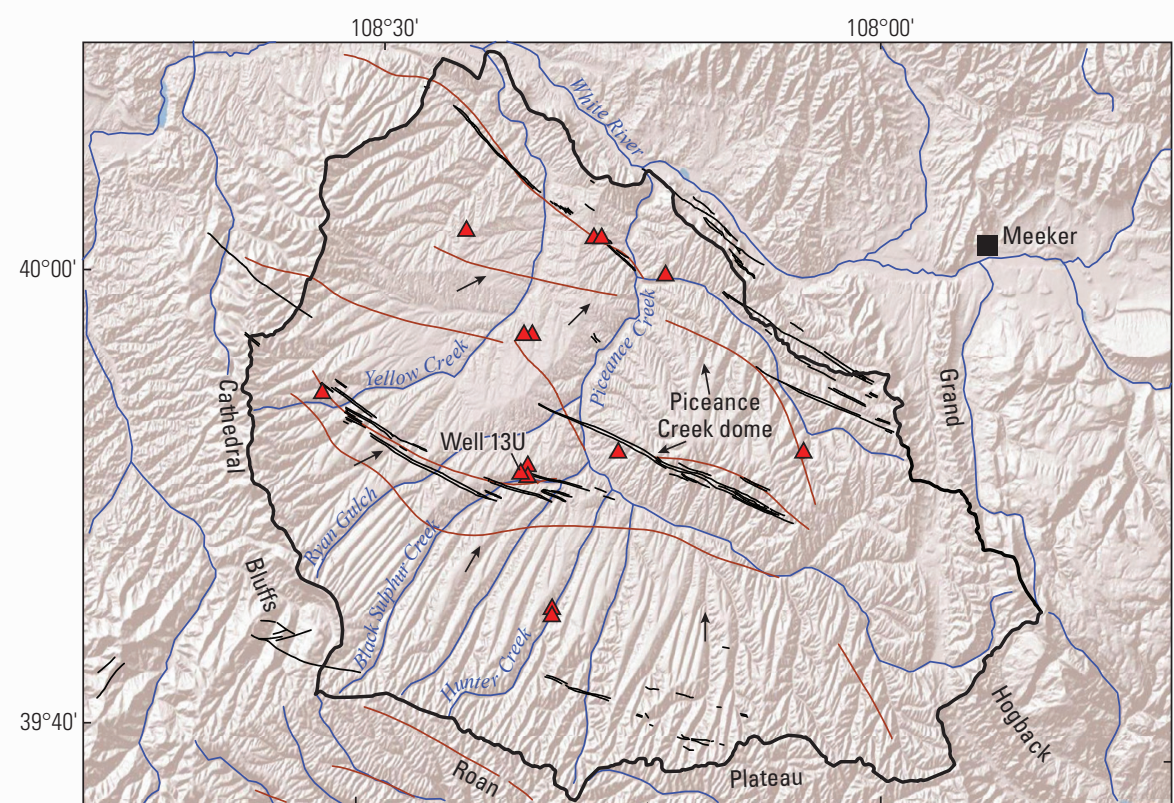

Base from Environmental Research Systems Institute (ESRI) digital data, 2009, 1:24,000 and U.S. Geological Survey digital data, 2010, 1:100,000 Universal Transverse Mercator, Zone 13 North

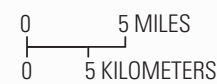

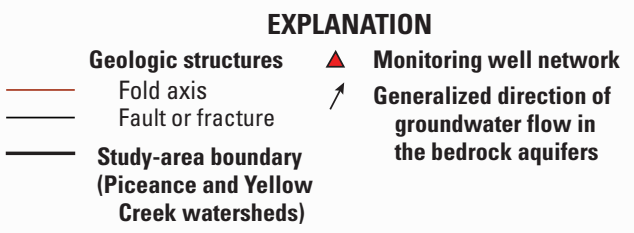

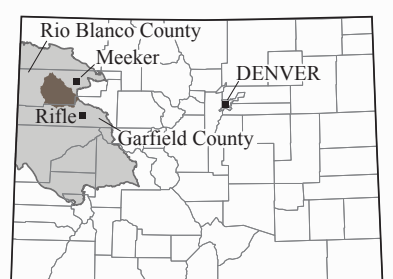

EXPLANATION

Study area

Piceance structural basin

Figure 1. Fourteen monitoring wells were sampled multiple times for a wide variety of chemical and isotopic constituents to characterize the chemistry and age of groundwater in bedrock aquifers. [Geologic structure from Hail and Smith $(1994,1997)$.]

\section{Key Findings}

- Concentrations of dissolved solids in groundwater exceeded the Federal secondary drinking-water standard of 500 milligrams per liter $(\mathrm{mg} / \mathrm{L})$ but generally were less than $1,500 \mathrm{mg} / \mathrm{L}$, except near the regional discharge area where concentrations in some wells exceeded 4,000 $\mathrm{mg} / \mathrm{L}$.

- Methane concentrations in groundwater ranged from less than 0.0005 to $387 \mathrm{mg} / \mathrm{L}$.

- The methane was predominantly biogenic in origin, although the biogenic methane was mixed with thermogenic methane in water from seven wells.

- Three BTEX compounds (benzene, toluene, and ethylbenzene) were detected in water from six wells, but none of the concentrations exceeded Federal drinking-water standards.

- Groundwater from the upper aquifer system had ages ranging from less than 1,000 years to about 20,000 years, whereas groundwater from the lower aquifer system had ages greater than about 10,000 years, and most ages were greater than 20,000 years.

\section{Key Implications}

- The presence of thermogenic methane and BTEX compounds in the aquifers indicates a connection and vulnerability to chemicals in deeper geologic units in the study area.

- Hydrocarbon migration in the area is complex, so collection of baseline data prior to gas-well installation and collection of timeseries data after gas-well installation is the best way to understand hydrocarbon migration in the study area.

- The presence of old groundwater in the aquifers has important management implications with respect to contaminant flushing times and water availability. 
The Study Area

Water-bearing zones in the Uinta and Green River Formations are the primary bedrock aquifers within the study area. In this study, the bedrock aquifers were divided into an upper aquifer system in the Uinta Formation and Parachute Creek Member of the Green River Formation above the Mahogany zone and a lower aquifer system in the Parachute Creek Member of the Green River Formation below the Mahogany zone (fig. 2). The Mahogany zone is a regionally extensive confining layer that separates the upper and lower bedrock aquifer systems.

The aquifers are important sources of water for people living and working in the area, and to streams and springs in the watersheds that support a variety of plant and animal communities. The study area contains rich energy resources in the forms of oil shale and natural gas (Johnson and others, 2010; Johnson and Rice, 1990), as well as mineral resources such as nahcolite (a sodium bicarbonate mineral) (Brownfield and others, 2010). Commercial development of the oil-shale resource has not begun as of 2013, although research on oil-shale development in the area is ongoing. Commercial production of natural gas in the Piceance structural basin has occurred since at least the 1950s and is expected to expand in the foreseeable future (Bureau of Land Management, 2013). Gas wells commonly produce from the Mesaverde Group (fig. 2) at depths greater than 10,000 feet below land surface (Colorado Oil and Gas Conservation Commission, 2012), although some gas also has been produced from geologic units above and below the Mesaverde Group. The base of the bedrock aquifers generally is less than 2,500 feet below land surface.

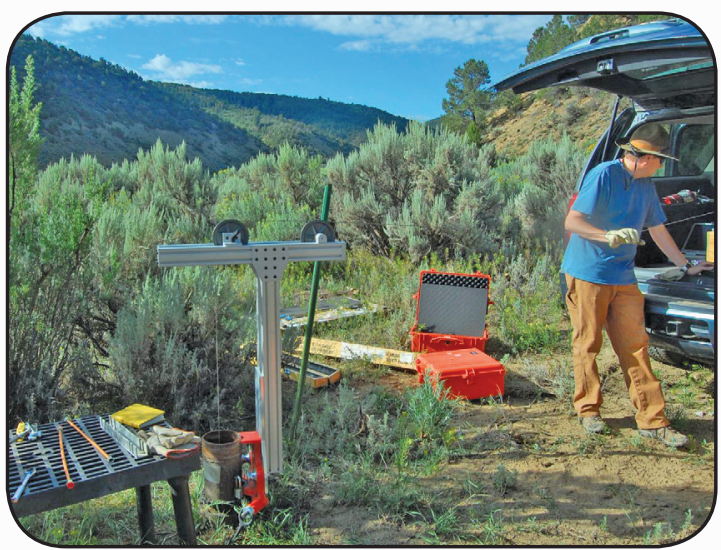

Discrete-depth samplers were used to collect water samples from most of the monitoring wells. Photographs by Peter McMahon (left) and Richard Moscati (above), U.S. Geological Survey.
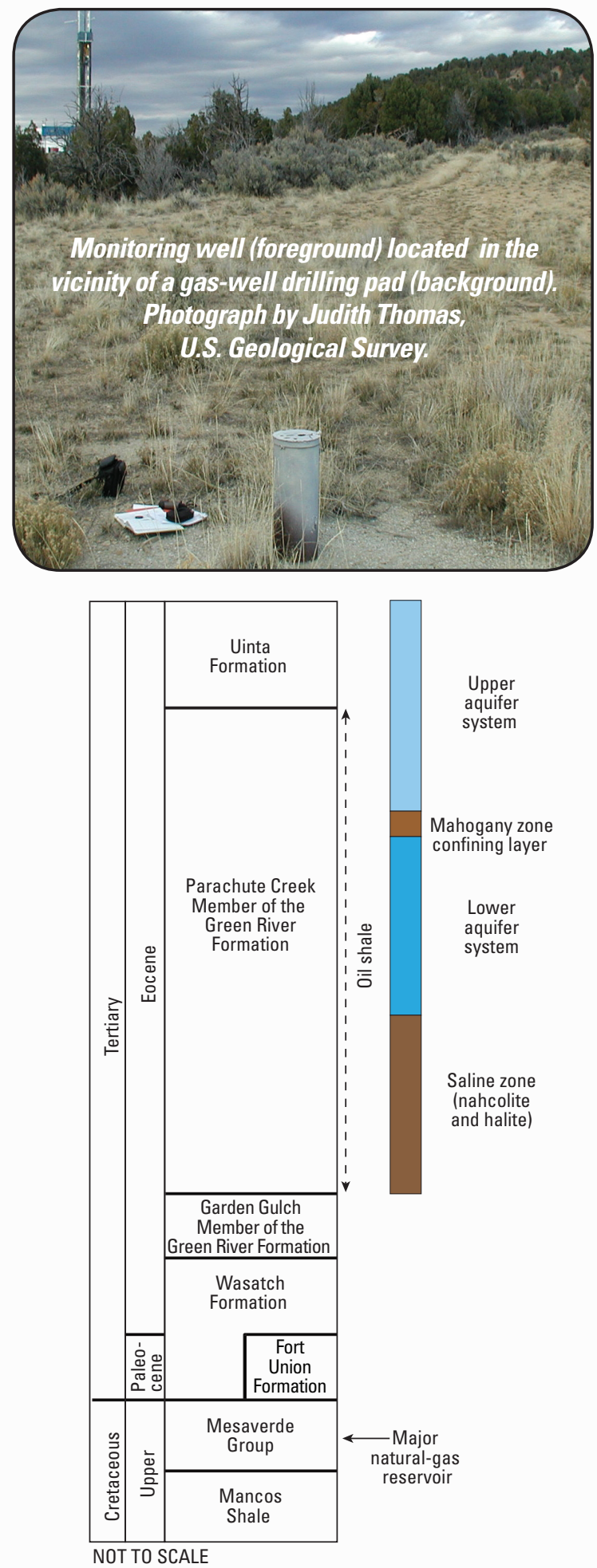

Upper quifer system

Mahogany zone confining layer

Lower quifer system

Saline zone (nahcolite and halite)

Figure 2. The primary bedrock aquifers are in the Uinta Formation and Parachute Creek Member of the Green River Formation, whereas natural gas commonly is produced from deeper geologic units such as the Mesaverde Group. [Figure modified from Johnson and Rice (1990) and Johnson and others (2010).] 


\section{The Study Design}

Fourteen monitoring wells completed in the bedrock aquifers were sampled in this study (fig. 1). Thirteen of the wells were selected from an inventory of existing wells and one well was installed for this study. In 2011 and 2012, all 14 wells were sampled for a wide variety of chemical and isotopic constituents. Five of the wells also were sampled quarterly in 2010 and 2011 for a smaller set of constituents to examine temporal changes in water quality. The chemical and isotopic constituents were selected to provide information on the overall chemical quality of groundwater, occurrence and distribution of chemicals that could be related to the development of underlying natural-gas reservoirs, and to better understand groundwater residence times in the flow system.

\section{Dissolved Solids in Groundwater}

Groundwater generally evolved from a mixed-cation-bicarbonatesulfate type water in the upper aquifer system to a sodium-bicarbonate type water in the lower aquifer system. Most of the dissolved solids in groundwater were produced by dissolution of minerals such as dolomite, pyrite, nahcolite, and halite. Ion exchange further altered the water chemistry by removing calcium and magnesium from solution and replacing them with sodium. Concentrations of dissolved solids in both aquifer systems exceeded the Federal secondary drinkingwater standard of $500 \mathrm{mg} / \mathrm{L}$ but generally were less than $1,500 \mathrm{mg} / \mathrm{L}$. Concentrations increased to more than $4,000 \mathrm{mg} / \mathrm{L}$ in the lower aquifer system near the regional discharge area at the northern end of Piceance Creek (fig. 3). Water from one well completed in the lower aquifer system near the regional discharge area had a dissolved-solids

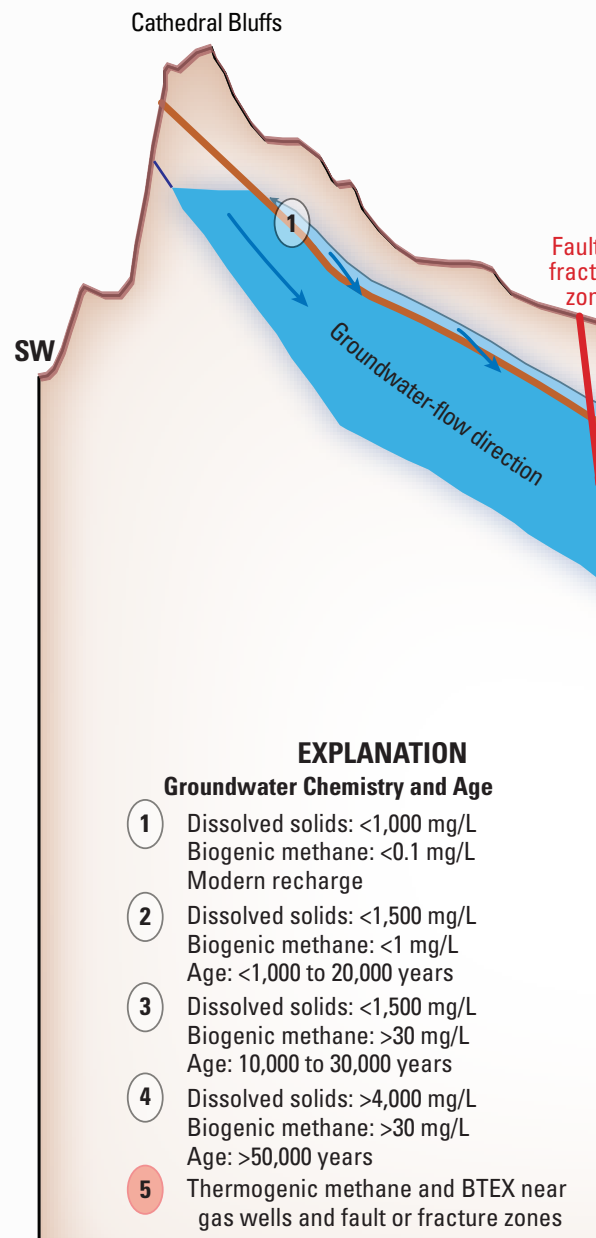

concentration of $47,600 \mathrm{mg} / \mathrm{L}$. High concentrations of bicarbonate and chloride in that sample are indicative of deeply circulating groundwater that interacted with nahcolite and halite minerals present at depth in what is known as the saline zone of the Parachute Creek Member. Only one water sample from the upper aquifer system had a chemical constituent (fluoride) concentration that exceeded a Federal primary drinking-water standard, whereas several samples from the lower aquifer system exceeded the drinking-water standards for fluoride $(4 \mathrm{mg} / \mathrm{L})$ and barium $(2 \mathrm{mg} / \mathrm{L})$.

Figure 3. Concentrations of dissolved solids and biogenic methane, and groundwater ages, increased as groundwater in the upper and lower bedrock aquifer systems moved from high-elevation recharge areas to regional discharge areas. Thermogenic methane and BTEX compounds were detected in groundwater near some gas wells and fault or fracture zones. Biogenic methane was produced locally in the aquifer systems, whereas thermogenic methane was produced in deeper geologic units below the aquifers. [Topography and aquifer boundaries modified from Day and others (2010). Gas well data downloaded from the Colorado Oil and Gas Conservation Commission (2012) on December 4, 2012. Chemistry and ages from this study.]

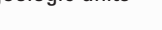




\section{Hydrocarbons in Groundwater}

Methane concentrations in groundwater ranged from less than 0.0005 to $387 \mathrm{mg} / \mathrm{L}$. There currently (2013) is no Federal drinkingwater standard for methane, but water containing methane at concentrations greater than about $28 \mathrm{mg} / \mathrm{L}$ could result in an immediate explosive hazard if used or stored in confined spaces (Eltschlager and others, 2001). Seven of the 14 wells produced water with methane concentrations greater than $28 \mathrm{mg} / \mathrm{L}$. The methane was predominantly biogenic in origin, although the biogenic methane was mixed with thermogenic methane in water from seven wells (fig. 4). One sample (from well 13U) contained 100 percent thermogenic methane that had an isotopic composition similar to that of some commercially produced natural gas in the Piceance structural basin (Johnson and Rice, 1990). The highest concentrations of biogenic methane occurred in the lower aquifer system (fig. 3) and were probably produced by microbial degradation of oil shale contained therein. In contrast, the thermogenic methane was produced by nonbiological processes in deeper geologic units below the aquifer systems and subsequently moved up into the aquifers (Johnson and Rice, 1990).

Three BTEX compounds (benzene, toluene, and ethylbenzene) were detected in small concentrations in water from six of the monitoring wells, but none of the concentrations exceeded a Federal primary drinking-water standard. Well 13U, for example, contained 0.4 to 1.1 micrograms per liter $(\mu \mathrm{g} / \mathrm{L})$ of benzenemuch less than the standard, which is $5 \mu \mathrm{g} / \mathrm{L}$. Five of the six wells that contained BTEX also contained at least a small amount of thermogenic methane. Taken together, the methane and BTEX data indicate that deep fluids interacted with groundwater in the aquifers.

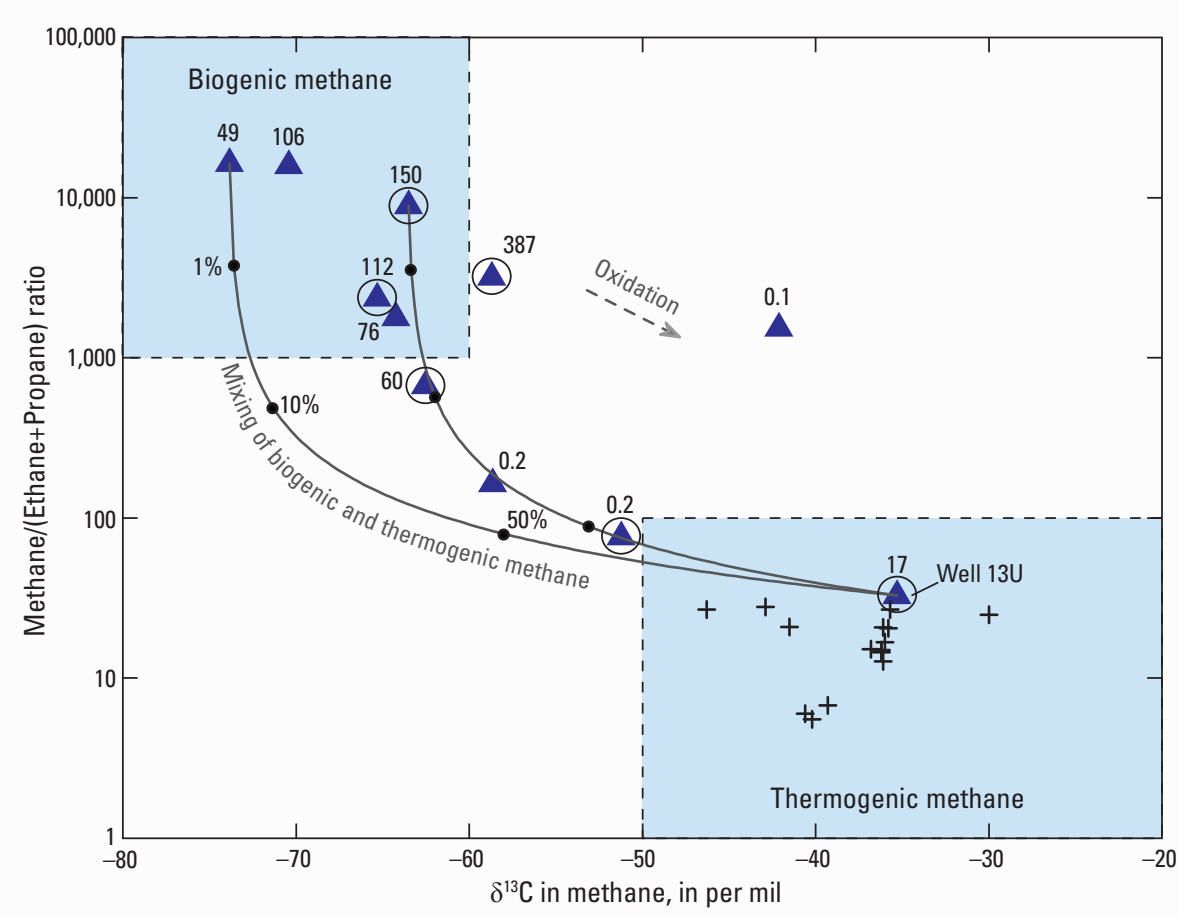

EXPLANATION
+ Natural gas in the Piceance structural basin (Johnson and Rice, 1990)

$1 \%$ Percentage of thermogenic methane in mixture

Figure 4. Most methane in the samples was biogenic, but some samples contained a mixture of biogenic and thermogenic methane. Samples from monitoring well $13 \mathrm{U}$ contained 100 percent thermogenic methane similar in composition to some natural gas produced in the Piceance structural basin; $\delta^{13} \mathrm{C}$, stable carbon isotopic composition. [The boundaries of the biogenic and thermogenic methane fields are modified from Bernard and others (1976) and Whiticar (1999).]

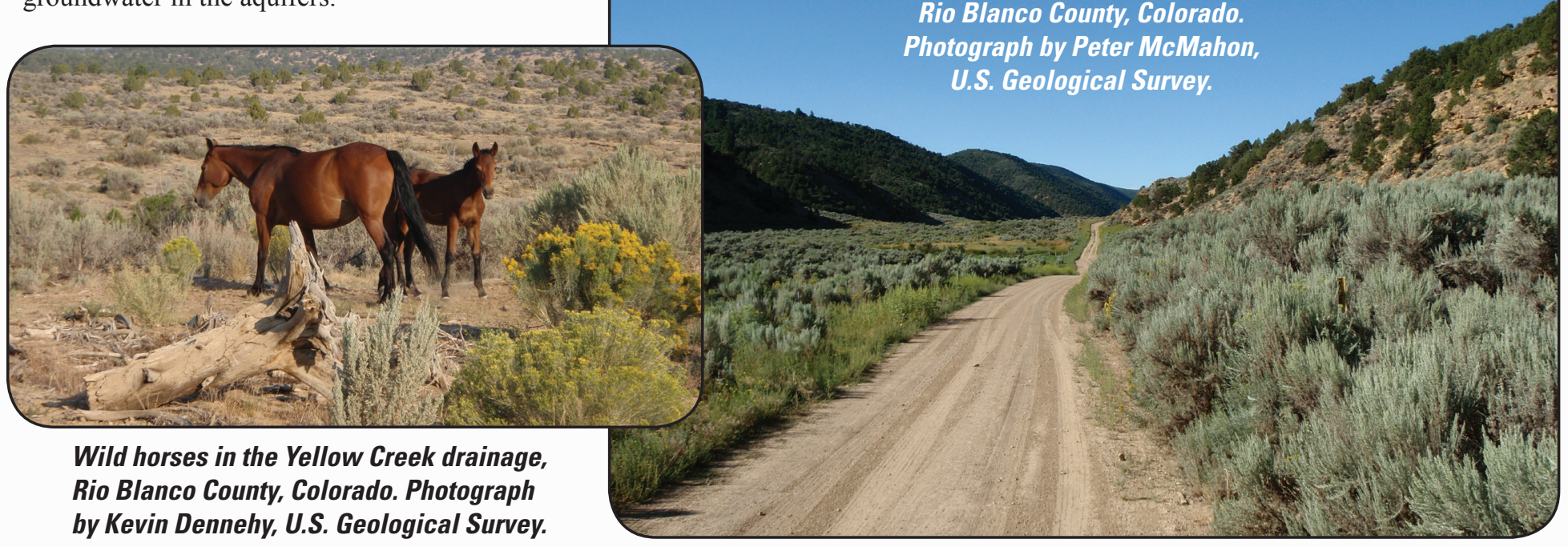




\section{Hydrocarbon Migration}

In general, the two most likely migration pathways for hydrocarbons in the study area are movement along natural geologic structures (faults, fractures, or fold axes) and movement through improperly sealed boreholes of gas wells. Regardless of the migration pathway, the presence of thermogenic methane in the aquifers indicates a connection and vulnerability to chemicals in deeper geologic units in the study area. Most monitoring wells that contained BTEX compounds or thermogenic methane had more gas wells than mapped geologic structures located within 1,500 feet of the wells (fig. 5). Most monitoring wells free of BTEX compounds and thermogenic methane did not have any gas wells located within 1,500 feet of the wells. These data indicate that hydrocarbon migration could be associated with gas wells in some locations, such as at well $13 \mathrm{U}$.

Monitoring well 13U, which contained small concentrations of benzene and 100 percent thermogenic methane, had seven gas wells and one mapped geologic structure located within 1,500 feet of the well (fig. 5). One of those gas wells, which was plugged and abandoned in 1990, was located within 60 feet of

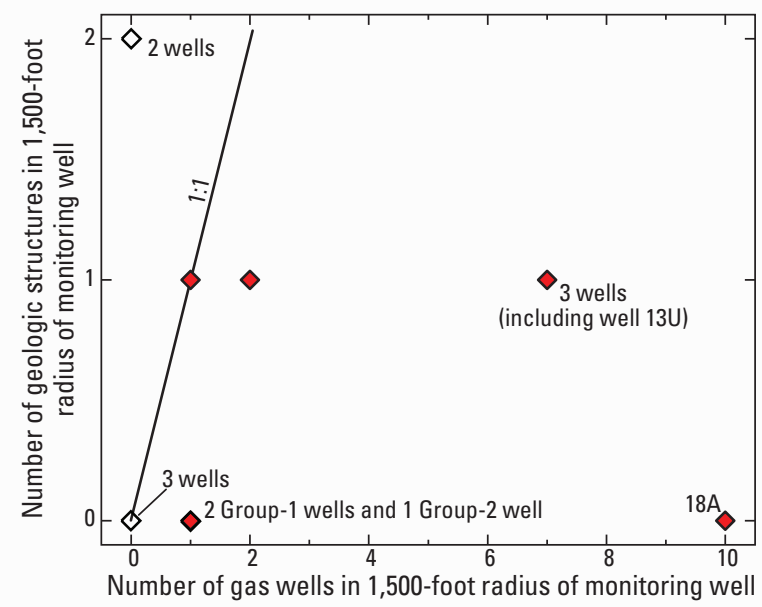

\section{EXPLANATION}

$\checkmark$ Group 1-Groundwater samples that contained BTEX compounds or some thermogenic methane

$\diamond$ Group 2-Groundwater samples that contained no BTEX compounds or thermogenic methane

Figure 5. Some samples that contained BTEX compounds or thermogenic methane appeared to be more closely associated with gas wells than geologic structures (faults, fractures, or fold axes), indicating that hydrocarbon migration could be associated with gas wells in some locations.

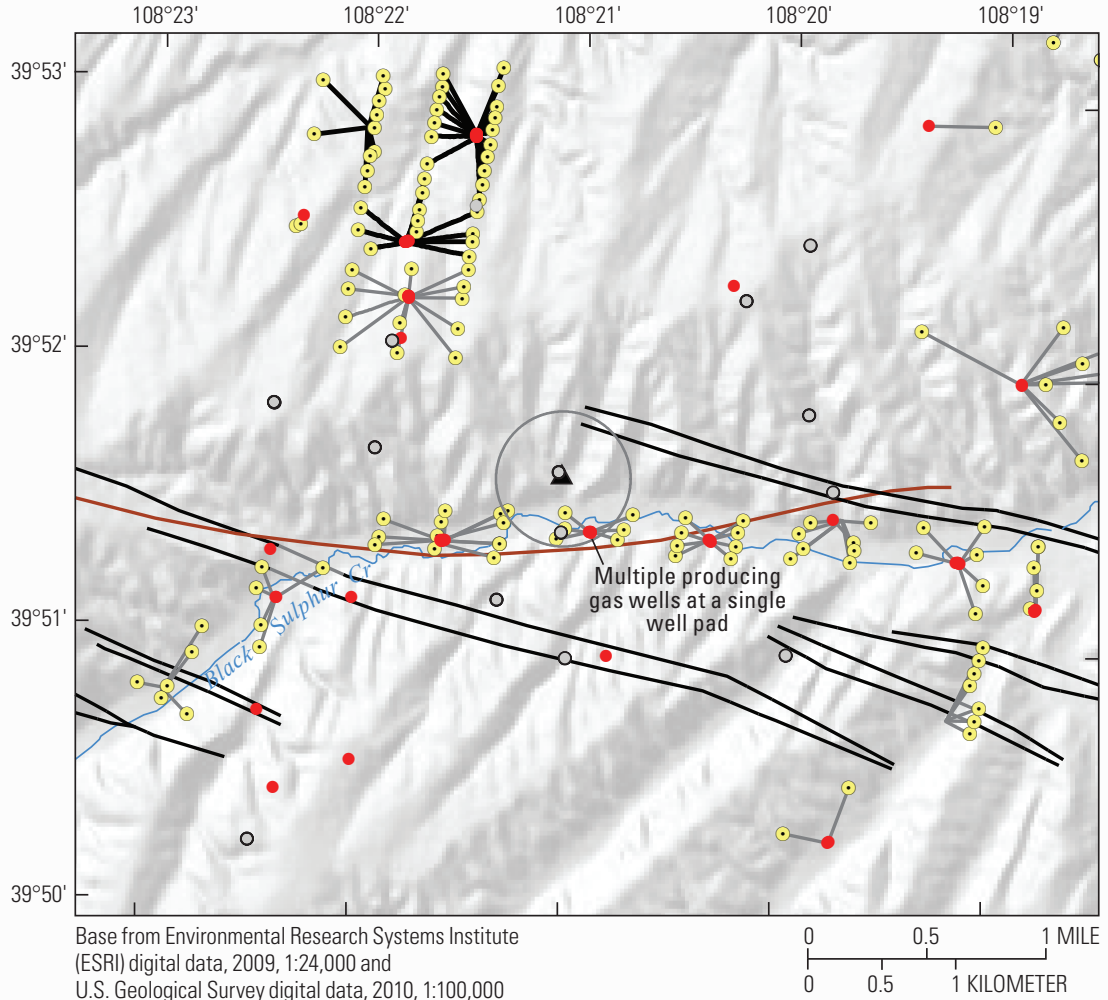

U.S. Geological Survey digital data, 2010, 1:100,000 Universal Transverse Mercator, Zone 13 North

\begin{tabular}{cl} 
Geologic structures \\
\hline \\
\hline \\
Fold axis \\
Fault or fracture \\
Bottom hole location and directiona \\
drill lines (Colorado Oil and Gas \\
Conservation Commission, 2012 \\
Bottom hole locations \\
$\quad$ Directional drilling lines
\end{tabular}

Oil \& gas wells (Colorado Oil and

Gas Conservation Commission, 2012)

- Abandoned

Producing

(-) Monitoring-well site 13 surrounded by 1,500 -foot buffer zone

Figure 6. Seven gas wells were located within a 1,500-foot radius of well site 13, including an abandoned gas well that was collocated with the monitoring wells. Water from all three monitoring wells at the site contained BTEX compounds and some thermogenic methane. [Geologic structure from Hail and Smith (1994, 1997).]

well 13U (fig. 6). Other features that were potentially relevant to the hydrocarbon chemistry of $13 \mathrm{U}$ were located outside the 1,500-foot zone but upgradient from 13U. These features include several faults or fractures (fig. 1) and an old test site for in-situ oil-shale retorting where natural gas was actually injected into the bedrock aquifer system in the late 1960s in an attempt to generate oil from the oil shale (U.S. Congress Office of Technology Assessment, 1980). The manner in which hydrocarbons migrated to well $13 \mathrm{U}$ is unclear because the relative contributions of nearby gas wells, geologic structures, and legacy contamination to hydrocarbon migration are not well understood. Ultimately, collection of baseline data prior to gas-well installation and collection of time-series data after gas-well installation is the best way to understand the roles of gas wells, geologic structure, and legacy contamination in hydrocarbon migration in the study area.

ollection of baseline data prior to gas-well installation and collection of time-series data after gas-well installation is the best way to understand the roles of gas wells, geologic structure, and legacy contamination in hydrocarbon migration in the study area. 


\section{Groundwater Ages}

Groundwater ages in the aquifers were evaluated using tritium, carbon-14, helium-4, and chlorine-36 data. Collectively, the data indicate that groundwater in high-elevation recharge areas was essentially modern (recharged since the 1950s) and became progressively older as the water moved downgradient in the flow system (fig. 3). Helium-4 data indicate that groundwater from above the Mahogany zone had ages from less than 1,000 years to about 20,000 years, whereas groundwater from within and below the Mahogany zone had ages greater than about 10,000 years, and most ages were greater than 20,000 years. Groundwater ages in the lower aquifer near the regional discharge area at the northern end of Piceance Creek appeared to be greater than 50,000 years. The old groundwater ages have important implications from a water management perspective. The parts of the aquifers with long groundwater residence times could have century- to millennium-scale flushing times if they were contaminated. The presence of old groundwater in parts of the aquifers also indicates that these aquifers may not be useful for largescale water supply because of low recharge rates.

\title{
Old groundwater ages have important implications
from a water management perspective.
}

\section{Study Limitations}

Results of this study should be considered in the context of some important limitations related to data availability. Fourteen monitoring wells were used to characterize groundwater chemistry and age in the 900 square-mile study area. This small number of wells represents a limitation in the ability to analyze the spatial variability of water chemistry and age in the bedrock aquifers. Few data on the chemical and isotopic composition of deep formation water below the aquifers were available, thus limiting the ability to understand their spatial variability and recognize if water from deeper formations entered the bedrock aquifers. Similarly, few data on the composition of natural gas from the study area were available. Such data would be useful for understanding the variability in gas composition and for possibly identifying which of the producing gas zones contributed thermogenic methane to the bedrock aquifers.

\section{Contact Information}

\author{
For further information, contact: \\ Peter McMahon (pmcmahon@usgs.gov) \\ Judith Thomas (juthomas@usgs.gov)
}

\section{References Cited}

Bernard, B.B., Brooks, J.M., and Sackett, W.M., 1976, Natural gas seepage in the Gulf of Mexico: Earth and Planetary Science Letters, v. 31, p. 48-54.

Brownfield, M.E., Mercier, T.J., Johnson, R.C., and Self, J.G., 2010, Nahcolite resources in the Green River Formation, Piceance Basin, Colorado, in U.S. Geological Survey Oil Shale Assessment Team, eds., Oil-shale assessment of the Piceance Basin, Colorado: U.S. Geological Survey Digital Data Series DDS-69-Y, chap. 2, 57 p., accessed February 14, 2012, at http://pubs.usgs.gov/dds/dds-069/dds-069-y/.

Bureau of Land Management, 2013, Reasonable foreseeable development scenario for oil and gas activities in the BLM White River Field Office, Rio Blanco, Moffat, and Garfield Counties, Colorado: accessed June 13, 2013, at http://www.blm.gov/co/ st/en/BLM_Programs/land_use_planning/rmp/white_river/documents/RFD.html.

Colorado Oil and Gas Conservation Commission, 2012, Colorado Oil and Gas Information System: accessed October 13, 2012, at http://cogcc.state.co.us/.

Day, M., Hansen, E., Gulliver, T., and McKinzie, B., 2010, Northwest Piceance Creek Basin hydrogeology, in Proceedings of the 30th Oil Shale Symposium, Golden, Colorado, October 18-20, 2010, accessed February 21, 2012, at http://www.costar-mines.org/oss/30/paper/Paper_14-02-Hansen_Erik.pdf.

Eltschlager, K.K., Hawkins, J.W., Ehler, W.C., and Baldassare, Fred, 2001, Technical measures for the investigation and mitigation of fugitive methane hazards in areas of coal mining: Office of Surface Mining Reclamation and Enforcement, 125 p., accessed February 8, 2013, at http://www.techtransfer.osmre.gov/ARsite/ Publications/Methane\%20Manual.pdf.

Hail, W.J., and Smith, M.C., 1994, Geologic map of the northern part of the Piceance Creek basin, northwestern Colorado: U.S. Geological Survey Miscellaneous Investigations Series Map I-2400, 1 map.
Hail, W.J., and Smith, M.C., 1997, Geologic map of the southern part of the Piceance Creek basin, northwestern Colorado: U.S. Geological Survey Miscellaneous Investigations Series Map I-2529, 1 map.

Johnson, R.C., Mercier, T.J., Brownfield, M.E., Pantea, M.P., and Self, J.G., 2010, An assessment of in-place oil shale resources in the Green River Formation, Piceance Basin, Colorado, in U.S. Geological Survey Oil Shale Assessment Team, eds., Oil-shale assessment of the Piceance Basin, Colorado: U.S. Geological Survey Digital Data Series DDS-069-Y, chap. 1, 197 p., accessed February 14, 2012, at http://pubs.usgs.gov/dds/dds-069/dds-069-y/.

Johnson, R.C., and Rice, D.D., 1990, Occurrence and geochemistry of natural gases, Piceance Basin, northwest Colorado: American Association of Petroleum Geologists Bulletin, v. 74, p. 805-829.

McMahon, P.B., Thomas, J.C., and Hunt, A.G., 2013, Chemistry and age of groundwater in bedrock aquifers in the Piceance and Yellow Creek watersheds, Rio Blanco County, Colorado, 2010-12: U.S. Geological Survery Scientific Investigations Report 2013-5132, 89 p.

U.S. Congress Office of Technology Assessment, 1980, An assessment of oil shale technologies: accessed January 25, 2013, at http://www.princeton.edu/ ota/disk3/ 1980/8004_n.html.

Whiticar, M.J., 1999, Carbon and hydrogen isotope systematics of bacterial formation and oxidation of methane: Chemical Geology, v. 161, p. 291-314.

-P.B. McMahon, J.C. Thomas, and A.G. Hunt 